\title{
Notary Role in the Implementation of The Cooperation Agreement Between Housing Developers and Land Owner
}

\begin{abstract}
Rahmatika Nur Hidayah $^{1}$ and Akhmad Khisni ${ }^{2}$
Abstract. Housing development cooperation between housing developers and owners of land to do to overcome the limitations of the amount of land and pressing capital needs. Generally in this cooperation landowners who provide land, while housing developers set aside, build housing and market it. But such cooperation is prone to risks for both sides, which could lead to disputes or disputes. Notary public officials in law is expected to help prevent the occurrence of the dispute or the dispute. Therefore, the authors are interested in conducting research on the issue, with the aim to determine the role of the Notary in the implementation of the cooperation agreement between the developer residential housing development and land owners. The study was conducted through library research using descriptive method by collecting data, collate, analyze and interpret. In conclusion, as follows: First, the legality of which is clean and clear $(\mathrm{CnC})$ is a very important factor in running the housing business. Second, the need for good faith from housing developers and landowners in implementing the cooperation agreement. Third, the Notary's role is very important in helping to prevent the risk of dispute or disputes by providing legal counseling and make a deed of agreement to provide legal certainty for housing developers and landowners.

Keywords: Notary Role; Cooperation Agreement; Developer and Land Owner.
\end{abstract}

\section{Introduction}

The public need to have a home at this time is very high, but is not supported by the availability of sufficient land. Vacant land on the wane and the price is more expensive, so that people difficult to have a decent home at an affordable price. Many housing developers mangalami difficulty finding land to develop housing projects to meet community needs. Currently the solution is mostly done by the developers of housing is to encourage cooperation with landowners to build and develop housing with all the trimmings. In this case the real estate developer involving landowners in the housing business, with a pattern of cooperation and profit-sharing in accordance with the collective agreement. In this partnership landowners to provide land, while housing developers set aside, build and market a housing or other property products. Cooperation between housing developers and land owners is a very good thing, because to build housing projects in need of funding or a relatively large capital. By way of such cooperation the capital needed housing developer to be reduced, while the land owner can sell the land more quickly at a better price.

Cooperation between housing developers and owners of the land is vulnerable to risks that could lead to problems if not anticipated by both parties. Risks for developers of housing is housing projects do not go as planned or loss caused by, among other things: (1) licensing out, (2) the land use is not in accordance with the spatial plan of the city, (3) lack of funds because the funds expected from banks or investors are not obtained, (4) the housing project is not sold, (5) the land in dispute. While the risk for landowners, among others: (1) the housing developer has raised a sign to be or advances from consumers but the house not being built, (2) the distribution of profits

\footnotetext{
${ }^{1}$ Students Master of Notary Law Faculty UNISSULA email: rahmatikanh@gmail.com

${ }^{2}$ Lecturer of Faculty of Law UNISSULLA.
} 
is not in accordance with the agreement, (3) housing projects stalled due to housing developers in debt to third parties, eg contractors, banks.

Such risks above shows almost everything related to the legal issues, which could lead to disputes or disputes for housing developers with land owners and stakeholders. Notary public officials in law is expected to help prevent disputes or disputes due to the risks mentioned above.

From the above description, the authors are interested in doing research and discussing through writing, entitled "Notary Role in the Implementation of the Cooperation Agreement between Housing Developers and Land Owner".

Based on issues above authors formulate several things, among others, the following:

1. What a very important factor in running a business in a housing project?

2. What basic things that must be held within the housing developers and landowners to co-operation goes well and smoothly?

3. What is the role of the Notary in the implementation of the cooperation agreement between the developer residential housing development and land owners?

With the discussion of these issues are expected to be known the extent of the role of the notary in the implementation of development cooperation between developers of housing and residential land owners.

\section{Research Methods}

Forms of research used in this paper is the literature research using descriptive method by collecting data from reference sources to be studied and studied, processing, collating data, then analyze and interpret, with the stages as follows: Collecting reference sources relating to the matter under study to study; Processing and compiling the data have been collected; To analyze and interpret.

\section{Results And Discussion}

The Central Statistics Agency (BPS) called a data backlog of housing in 2016 reached 11.5 million households. This is ironic because in the midst of such major scarcity, it should be smeared with the act of rogue developers. Figures errant developers is "only" hundreds of complaints from a total of about 800 thousand in property sales each year. However, property developers fraudulent practices is like an iceberg because there are buyers who are reluctant to report it, one must be willing to undergo a protracted mechanism to get their rights back. ${ }^{3}$

From the records of the Indonesian Consumers Foundation (YLKI), property fraud ranks second in the last five years after a banking fraud. It becomes interesting because every day users of banking services is enormous. While in the property sector, consumers tend to be less. YLKI finds no systemic problem of the housing industry. Because of its tendency is stable and the problem was just that's it. Only the perpetrators are changed. This proves there is nothing wrong from the housing industry system, "said Mustafa Aqib Bintoro, complaints and legal staff YLKI. In 2014, the number of complaints received 157 complaints, and then increased in 2015 as many as 160 complaints. This number decreased to 123 complaints in 2016. Nevertheless, this figure does not depict a mountain of actual cases because of a complaint may consist of a number of victims. This does not include customers who are reluctant to report and choose mengikhlaskan. Of the complaint, the problem vary, of failing to get up, in default, to difficulty making the refund for the developer ran

\footnotetext{
${ }^{3}$ https://www.tirto.id/penipuan-properti-marak-karena-manfaatkan-kelemahan-konsumen-cxlo
} 
away. YLKI see the complexity of the problem lies in the implementation of property laws "not optimal". For example, to be able to market housing, the developer must be pocketed at least some permissions such as IMB, the status of land ownership, the availability of public facilities and fasus, until the building is completed to house at least 20 percent. It is listed in Article 42 paragraph 2 of Act No. 1 of 2011 on housing and Settlement Region. ${ }^{4}$

Here the author provides two examples of cases resulting from violations by the developer housing (case I), and violation by the owner of the land (case II). The second example of this case equally impact on the dispute or disputes which resulted in neglected housing construction / fail wake.

Case I: Housing Pondok Pondok Rajeg Hills area Rajeg, District Cibinong, Bogor regency. Housing developers argued experiencing financial difficulties, so the impact on the abandonment of housing construction. Investigate a investigate, ground to be built was not owned housing developer. 800 square meters of land that is owned Nurhadi, local residents who cooperate with housing developers sharing system 40 percent of the land owners, 60 per cent of housing developers. That was just awarded if all the houses have been sold. Some consumers reported the case to the Depok Police, because the aggrieved has paid advances to housing developers. (Source: Tirto.id, dated 27 September 2017).

Case II:subsidized housing in Bitai Region, District Jaya Baru, Banda Aceh. Five of those consumers as victims allegedly harmed tens of millions of rupiah has reported the case to Mapolresta Banda Aceh. Victims report that has deposited an advance, but never home built by housing developers. Housing developer explained that thes house construction type 36 was due to constrained on landowners who do not allow for continued development. (Source: rri.co.id, dated October 27, 2018)

From some cases the property, such as the two examples above cases almost all related to legal issues, resulting in perselisian problem or dispute against housing developers and landowners. The problem could also affect adversely the relevant parties, among others: customers, contractors, and building stores. Notary public officials in law is expected to help prevent disputes or disputes due to the risks mentioned above.

\section{Notary understanding}

In Act No. 2 of 2014 concerning amendments to the Act No. 30 of 2004 concerning Notary, chapter 1 is a notary is a public official who is authorized to make the deed authentic and have the other authorities referred to in this Act or under other laws. ${ }^{5}$

\section{Notary authority}

In Act No. 2 of 2014 concerning amendments to the Act No. 30 of 2004 concerning Notary, Article 15 paragraph (1) Notary authorized to make the deed authenticity of all deeds, agreements, and determination required by legislation and / or desired by the stakeholders to be stated in the Deed authentic, guaranteeing the creation date of the Deed, save deed, giving grosse, copy and quote deed, all of it along the manufacture of Deeds was not also be assigned or excluded to the other officer or other person designated by the law. In addition to the authority referred to in paragraph (1), in paragraph (2) Notary authorities also:

\footnotetext{
${ }^{4}$ https://www.tirto.id/seribu-akal-pengembang-nakal-cxlg

${ }^{5}$ Act No. 2 of 2014 on the Amendment of Act No. 30 of 2004 on Notary.
} 
- certify the signatures and set a firm date in the letter under the hand by enrolling in special books;

- posted a letter under the hand by enrolling in special books;

- make a copy of the original letter under the hand in the form of a copy that contains a description as written and illustrated in the letter in question;

- approve their compatibility with a photocopy of the original letter;

- provide legal counseling in connection with the manufacture of the Deed;

- make Deed relating to land; or

- make treatise deed auction.

In addition to the authority referred to in paragraph (1) and (2), in paragraph (3) Notaries have other powers stipulated in the legislation. ${ }^{6}$

\section{Notary liabilities}

In Act No. 2 of 2014 concerning amendments to the Act No. 30 of 2004 concerning Notary, Article 16, paragraph (1) in the running position, the Notary shall: ${ }^{7}$

- acting trustworthy, honest, thorough, independent, impartial, and safeguard the interests of those involved in legal actions;

- make Deed in the form of Minuta Deed and save them as part of a Notary Protocol;

- attach a letter and documents and fingerprints penghadap on Minuta Deed;

- Grosse issued Deed, copy of Deed or Deed Excerpt by Minuta Deed;

- provide services in accordance with the provisions of this Act, unless there is a reason to reject it;

- keep secret everything about the deed he made and all information obtained in order to manufacture in accordance with the deed of oath / pledge of office, unless the law otherwise provides;

- stapling deed he made in one (1) month to book that contains no more than 50 (fifty) Acts, and if the number of deed can not be contained in one book, The deed can be bound to more than one book, and record the number of Minuta Deed, month, and year of manufacture on the cover of each book;

- make a list of the Deed of protest against not being paid or non-receipt of securities;

- make a list of the Deed of being pleased with a will chronologically manufacture deed every month;

- send a list of deed referred to in the letter $\mathrm{i}$ or register zero with respect to the will to probate register at the ministry center that held government affairs in the field of law within 5 (five) days in the first week of the following month;

- noted in his Repertorium delivery date will list at end of each month;

- have a seal or stamp which contains the symbol of the Republic of Indonesia and the space encircling written the name, position, and the position in question;

- read deed before penghadap in the presence of at least two (2) witnesses, or four (4) witnesses specifically for the manufacture Deed testament under the hand, and signed on the spot by penghadap, witnesses and Notary; and

- Notary candidates receive internships.

\footnotetext{
${ }^{6}$ Act No. 2 of 2014 on the Amendment of Act No. 30 of 2004 on Notary.

7 Ibid.
} 
Volume 6 Issue 2, June 2019

\section{Deed Understanding}

Deed of agreement is: "Letter of proof made in advance and in the presence of a notary, which contains the rules or clauses on the rights and obligations of legal subjects, where the legal subject that one is entitled to an achievement, while the subject of other legal obligation implementing achievements in accordance with the agreement made between them" 8

The elements listed in this definition, includes: (1) the letter of proof, (2) the competent authority to make a deed, (3) the subject of law, and (4) their achievement. His accomplishments, is to do something, do something and not do anything. Doing something means that the parties or the subject of law have rights and obligations are reciprocal to what have been agreed.

According to Article 1313 of the Civil Code, "A treaty is an act by which one or more persons bind himself to one or more other people". ${ }^{9}$

\section{Terms of Legal Agreement under the Civil Code}

According to Article 1320 of the Civil Code defines four terms validity of the agreement include: 10

- Both Sides their agreement

The agreement is governed by Article 1320 paragraph (1) of the Civil Code, the agreement is a statement rapprochement between the will of one person or more with other parties. Appropriate it is a statement, because it will not be visible or known to others.

- Ability to Perform Deeds Law

Acting prowess is the skill or ability to perform legal acts. Legal act is an act which would give rise to legal consequences. People will have an agreement must be people who are competent and authorized to perform legal acts, as required by law.

- Their object of agreement

In the literature mentioned that the object of the agreement is the achievement (of agreement). Achievement is what the debtor's obligations and what are the rights of creditors. Achievement consisting of: (1) give something, (2) do something, and (3) does nothing.

- Their causes of the Halal

Article 1320 of the Civil Code does not explain the sense orzaak (causes kosher). In Article 1337 of the Civil Code only mentioned causes are forbidden. One reason is prohibited if it is contrary to law, morals and public order.

\section{Principles of Law of Engineering Manufacture Deed}

Principles of the law of the deed is not specifically listed in the Act No. 2 of 2014 concerning amendments to the Act No. 30 of 2004 concerning Notary, yet the principles contained in the Civil Code. Legal principles contained in the Civil Code, which has a very close relationship with the deed, namely: ${ }^{11}$

- Principle consensualism

\footnotetext{
${ }^{8}$ Salim HS., , 2017, Teknik Pembuatan Akta Perjanjian (TPA DUA), (Depok: PT RajaGrafindo Persada, p. 25.

${ }^{9}$ Tim Pustaka Buana, 2017, Kitab Lengkap, Kitab Undang-Undang Hukum Perdata, Pustaka Buana, p. 287.

${ }^{10}$ Salim HS., Op.Cit, p. 29.

${ }^{11}$ Ibid, p. 10.
} 
Consensualism principle can be inferred from Article 1320 paragraph (1) of the Civil Code. In the article it is determined that one of the conditions the validity of the agreement, ie the agreement of both parties.

- The principle of freedom of contract

The principle of freedom of contract listed in Article 1338 paragraph (1) of the Civil Code, which reads: "All the agreements made legally valid as law for those who make it"

- Pacta sunt servanda principle (the principle of Rule of Law)

The principle of pacta sunt servanda, or referred to as the principle of legal certainty, where a judge or a third party must respect the substance of a contract made by the parties, can be summed up in Article 1338 paragraph (1) of the Civil Code, which reads: "The agreement was made legally valid as law ".

- The principle of good faith

The principle of good faith may be inferred from Article 1338 paragraph (3) of the Civil Code, which reads: "Agreement must be implemented with good-faith effort". A good-faith principle is a principle in which the parties must implement the substance of the contract based on a firm belief or conviction or good will of the parties.

- Principle of Personality

The principle of personality can be seen in Article 1315 and Article 1340 of the Civil Code. Article 1315 of the Civil Code states: "In general, a person can not hold a commitment or agreement other than to itself" Article 1340 of the Civil Code reads: "Agreement is only valid between the parties who made it".

\section{Legality}

Legalitas are clean and clear $(\mathrm{CnC})$ is a very important factor in running the business of housing, because all activities from start purchasing land, build, and market a home touch with the legislation, both government regulations and local regulations. Before starting the housing project, the legality of which should be investigated are:

- Legality of Land. The legality of the land can be done by checking whether or not the original ownership certificate to the National Land Agency (BPN) local.

- Licensing and Land Use. Licensing and land use can be checked to BAPEDA or the City Planning Office.

- Physical mastery over the Land. This can be done by check directly to the location in order to see the situation and the physical condition of the land.

\section{The stages of Housing Development Cooperation}

In general, there are several steps to be taken, as follows:

- Phase Observation and Testing of Legality Land

At this early stage of housing developers to observe the landscape and checking the legality of land that will be the object of cooperation. At this stage the general housing developers appealed to the notary, although this can be done by the developer housing.

- Negotiations stage

At this stage the housing developers and landowners to negotiate the important points that should be agreed upon, among other things: a) the price of land; b) money sign so and advances; c) for the results.

- Phase Signing Cooperation Agreements

At this stage the housing developers and landowners, and the witnesses signed the cooperation agreement before a Notary. After a letter of agreement signed by the 
parties, then start Berlakulah rights and obligations of both parties. Therefore, usually upon signing of the letter of agreement was followed by the beginning of the fulfillment of obligations of the parties, among other things: ${ }^{12}$

- Landowners hand over land titles have been split certificates, which solution is still the certificate on behalf of the land owner. Besides landowners also give power of attorney to housing developers to do the licensing, land development, real estate development, marketing and other powers.

- Housing developers hand over money to the owner of the land as payment for the first term, for example, about $25 \%$ of the total value of the land.

- Project execution stage

At this stage, developers of housing starts working on the project, such as planning, manage licensing and legality, doing preparatory work project site, working on the development of facilities and infrastructure, as well as building units. Along with all that work, can sell the house with the various strategies. ${ }^{13}$

- Stage Sharing

For results conducted during the housing units are built from unsold. For the results received by the parties in accordance with the agreement on a letter of agreement.

\section{Housing Development Cooperation Agreement}

To prevent a conflict or dispute, then the housing development cooperation schemes should be done with a clear and detailed provisions agreed with the letters made a cooperation agreement and signed by the parties before the Notary. Important points to be agreed upon in the letter of agreement, among others:

- Name cooperation and the scope of the agreement.

- Duration of the agreement.

- The value of land / assets.

- Payment of land value.

- The sharing of profit and loss burden.

- Obligations of the parties.

- Sanctions.

- Circumstances compel / force majeure.

- Dispute resolution.

- Cover / Witnesses

To protect money for proceeds from the sale of housing units should be created standing instruction that ordered the bank to allocate / transfer the money to the account of each party that amount in accordance with the agreement. This is very important especially if the land owner entered into a Limited Liability Company (PT). Besides all the land documents in order to be recorded in the Notary Office during the period of cooperation, with made agreement governing the certificate storage.

In the process of the implementation of all these very important role of the Notary in outreach to explain the main points of the agreement and its contents until the deed of agreement was approved and signed by the parties.

\footnotetext{
12 Ranti Fauza Mayana, 2019, Perjanjian Dengan Pihak Ketiga, Jakarta: Program MBA Mini Properti, p. 10.

${ }^{13}$ Asriman A. Tanjung, 2017, Cara Benar Meraih Sukses di Bisnis Developer Properti, Jakarta:

PT Gramedia Pustaka Utama, p. 116.
} 


\section{Conclusion}

1. Legality clean and clear $(\mathrm{CnC})$ is a very important factor in running the business of housing, which makes the project can proceed smoothly as expected.

2. It needs a good faith from housing developers and landowners in implementing the cooperation agreement is good, honest and mutually beneficial.

3. Notary very important role in helping to prevent the risk of dispute or disputes by providing legal counseling and make a deed of agreement to provide legal certainty for housing developers and landowners.

\section{Bibliography}

\section{Book}

[1] H. Salim HS., 2016, Teknik Pembuatan Akta Satu, Jakarta, PT. RajaGrafindo Persada.

[2] Salim HS., 2017, Teknik Pembuatan Akta Perjanjian (TPA Dua), Depok, PT. RajaGrafindo Persada.

[3] Salim HS., 2018, Peraturan Jabatan Notaris, Jakarta, Sinar Grafika.

[4] Wawan Muwan Hariri, 2011, Hukum Perikatan, Bandung, CV. Pustaka Setia.

[5] Hadin Muhjad, dkk, 2018, Eksistensi Notaris dalam Dinamika Hukum dan Kebijakan, Yogyakarta, Genta Publishing.

[6] Freddy Harris, dan Leny Helena, 2017, Notaris Indonesia, Jakarta, PT. Lintas Cetak Djaja.

[7] Tim Penulis Leks\&Co, 2018, Hukum Properti, Bandung, PT. Citra Aditya Bakti.

[8] Asriman A. Tanjung, 2017, Cara Benar Meraih Sukses di Bisnis Developer Properti, Jakarta, PT. Gramedia Pustaka Utama.

\section{Paper}

[1] Ranti Fauza Mayana, 2019, Perjanjian dengan Pihak Ketiga, Jakarta, Program MBA Mini Properti.

\section{Constitution}

[2] Tim Pustaka Buana, 2017, Kitab Lengkap, Kitab Undang-Undang Hukum Perdata, Pustaka Buana.

[3] Act No. 2 of 2014 on the Amendment of Act No. 30 of 2014 About the Notary.

\section{Internet}

[1] https://www.tirto.id/penipuan-properti-marak-karena-manfaatkan-kelemahankonsumen-cxlo

[2] https://www.tirto.id/seribu-akal-pengembang-nakal-cxlg

[3] http://m.rri.co.id/bandaaceh/post/berita/590029/ragam/kasus dugaan penipuan rumah subsidi develop er janji akan kembalikan dp korban.html 